ACTA MYCOLOGICA

Vol. 41 (2): 319-328

2006
Dedicated to Professor Alina Skirgietto

on the occasion of her ninety fifth birthday

\title{
Lichens of red oak Quercus rubra in the forest environment in the Olsztyn Lake District (NE Poland)
}

\author{
DARIUSZ KUBIAK \\ Department of Mycology, University of Warmia and Mazury in Olsztyn \\ Oczapowskiego 1A, PL 10957 Olsztyn, darkub@uwm.edu.pl
}

Kubiak D.: Lichens of red oak Quercus rubra in the forest environment in the Olsztyn Lake District (NE Poland). Acta Mycol. 41 (2): 319 328, 2006.

A list of 63 species of lichens and 4 species of lichenicolous fungi recorded on the bark of red oak (Quercus rubra L.) in Poland is given. Literature data and the results of field studies conducted in the forest in the Olsztyn Lake District between 1999 and 2005 are used in the report. Fifty five taxa, including lichens rare in Poland, for instance Lecanora albella, Lecidella subviridis, Ochrolechia turneri, were recorded.

Key words: lichens (lichenized fungi), lichenicolous fungi, red oak (Quercus rubra), Poland

\section{INTRODUCTION}

Rich lichen biotas, usually comprising numerous specific species, are associated with the genus Quercus L. both in Poland (Cieśliński, Tobolewski 1988; Rutkowski 1995) and in other parts of Europe (Alvarez, Carballal 2000; Zedda 2002; Engel et al. 2003). Many rare or very rare lichen species in Poland and taxa considered to be extinct have been found to colonise oak bark in Poland (Cieśliński, Tobolewski 1988; Rutkowski 1995; Rutkowski, Kukwa 2000; Fałtynowicz 1991). Its diversified texture provides niches suitable for different lichen species while the phorophyte's longevity influences the richness and diversity of its lichen biota. The occurrence of native oak species (Quercus robur, Q. petraea) in various forest communities is also significant (Matuszkiewicz 2001; Modrzyński et al. 2006; Danielewicz, Pawlaczyk 2006). However, despite abundant data on the occurrence of lichens on oak bark, the lichen biota of this phorophyte has not been studied thoroughly and extensively.

In Poland, the genus Quercus is represented by three native species ( $Q$. robur, $Q$. petraea, Q. pubescens) and several alien, mostly North American, species. Quercus rubra $\mathrm{L}$. is the only taxon of many introduced species to have acclimatised in natural forest habitats in Poland (Król 1967; Hereźniak 1992). At the same time, the number of introduction sites and its total cultivation area exceed those of all other 
deciduous species introduced in Polish forests (D a nielewicz, Pawlaczyk 2006). Quercus rubra is native to eastern parts of North America. It usually grows in lowland and submontane areas, and reaches $1600 \mathrm{~m}$ above sea level in the mountains (Browicz 1953). Its native range covers the area from Nova Scotia in the north to Alabama and Texas in the south, reaching the belt of Central American prairies in the west, and it generally corresponds to the eastern (Appalachian) forest region where deciduous forests that lose their leaves for winter are the basic type of vegetation (Appalachian oak forest region) (Podbielkowski 1995). In the native range, Quercus rubra grows on a variety of soils and in topographically diversified areas, often forming pure stands.

Species of the genus Quercus, both native and acclimatised, have usually been treated inclusively in lichenological research in Poland. Although some authors draw attention to the interesting lichen biota of red oak (Zalewska et al. 2004), only few provide extensive relevant information (Tyszkiewicz 1935; Dziabaszews ki 1962; Glanc 1969; Glanc, Kapuściński, Król 1971; Kukwa 2002; Kubiak 2005). The lack of detailed studies on species diversity, particularly important in the case of $Q$. rubra, the most widespread of alien species, encouraged the present author to examine the lichen biota of this phorophyte in depth.

\section{STUDY AREA}

Quercus rubra sites located in the Olsztyn Lake District in the municipal forests of the city of Olsztyn, in the Las Warmiński reserve and the Kamienna Góra reserve as well as in forest sections 51, 104 and 523 of the Nowe Ramuki forest district were examined. The sites are usually mid-forest cultivations covering a total surface area of 0.10-0.05 ha. The tree forms avenues, and occurs along section lines or forest roads less frequently. Single trees, probably self-sown, are also noted. The oldest sites of Quercus rubra in the area date back to the 1880s and are mostly the remains of Experimental Forest Areas established by German foresters (cf. Tumiłowicz 1965, 1967). The majority of the study sites come from this period.

The Olsztyn Lake District belongs to the western part of the Masurian Lake District (Kondracki 1998). The region is characterised by significant terrain diversification. Rolling uplands of the clayey ground moraine constitute the northern part of the Olsztyn Lake District, while hilly uplands and kettles in outwash plains, built from sands and gravels covered by expansive forests called the Nidzica Forest (Zaręb a 1978), abundant in lakes, form the southern part. The altitudes of moraine hills along the peripheries of the mesoregion slightly exceed $200 \mathrm{~m}$ above sea level and are significantly lower in the central part.

A greatly diversified plant cover is a feature of the Olsztyn Lake District, located in the transitional zone where elements of the oceanic and continental climates clash. Occurrence ranges of numerous plants, including forest-forming trees, characteristic both of central and western Europe (Atlantic flora) and of northern Europe (subboreal and boreal species), run and cross in the area. Durmast oak Quercus petraea (Boratyńsk a 1979), sycamore Acer pseudoplatanus (Boratyński 1979) and beech Fagus sylvatica (Tokarz 1971) reach their north-eastern limits of occurrence ranges in the Olsztyn Lake District. Norway spruce Picea abies (Jutrzenka-Trzebiatowski, Fenyk 2001) reaches the south-western limit of the boreal 
range. The ranges of main forest-forming species determine the shape and character of entire forest communities. Associations characterised by the continental type of range: Peucedano-Pinetum, Seratulo-Pinetum and Tilio-Carpinetum (subboreal variety), reach their western limits in the area while associations characterised by the subatlantic range or similar to it: Fago-Quercetum, Luzulo pilosae-Fagetum, StellarioCarpinetum, Galio odorati-Fagetum or Leucobryo-Pinetum, reach their eastern limits (Matuszkiewicz 2001).

\section{MATERIAL AND METHODS}

Detailed field studies were conducted in 2005. Data collected by the author in the period between 1999 and 2005 were additionally used. In total, 16 Querqus rubra sites located within forest complexes previously studied lichenologically were analysed. Critical taxa (sterile sorediate lichens, species of the genus Usnea) were determined using chromatography methods (TLC), performed according to the procedures specified by Orange, James and White (2001), in the Department of Mycology, University of Warmia and Mazury in Olsztyn, and the Department of Plant Taxonomy and Nature Protection, University of Gdańsk. Names of lichens and lichnicolous fungi are given after Fałtynowicz (2003) and Kukwa and Diederich (2005), red list categories of lichens after Cieśliński, Czyżewska and Fabiszewski (2003) and Cieśliński (2003b).

The collected herbarium material is deposited in the Herbarium of the Department of Mycology, University of Warmia and Mazury in Olsztyn (OLTC-L). The taxa are listed alphabetically. Source studies are specified in the case of taxa reported in earlier publications. The number of sites and their general location is given for the taxa recorded in the present study (Tab. 1).

\section{RESULTS}

A total of 55 species of lichens and 4 species of lichenicolous fungi were recorded in the study sites (Tab. 1). Between 11 and 25 species were recorded in individual sites, and 19 species on average. Taxa with crustose thalli dominate (39 species); lichens with foliose thalli ( 8 species) or with fruticose thalii $(5$ species $)$ and dimorphic species (Cladonia spp.; 4 species) are less numerous. The following species were recorded most frequently: Hypogymnia physodes, Cladonia coniocraea, Platismatia glauca, Lepraria incana, Mycoblastus fucatus, Pertusaria amara, Parmelia sulcata, Phlyctis argena, Buellia griseovirens, Lecanora pulicaris, Melanelia fuliginosa, Parmeliopsis ambiqua and Ochrolechia androgyna. Except Ochrolechia androgyna, these thalli are frequent or common, moderately or significantly ubiquitous. This group is responsible for the formation of crustose or crusote-foliose epiphytic communities, typical of this phorophyte, where taxa with fruticose thalli are recorded only sporadically. Twelve taxa (23.2\% of the biota) were recorded in single sites, mostly on single trees. These are: Amandinea punctata, Anisomerydium polyporii, Arthonia spadicea, Bacidina arnoldiana, Chaenotheca ferruginea, Chaenothecopsis pusilla, Lecanora albella, L. carpinea, Lecidella subvirdis, Ochrolechia turneri, Placynthiella icmalea, Scoliciosporum chlorococcum and Xanthoria polycarpa. Both common species, characterised by a broad ecological scale, and rare or very rare species 
Table 1

Lichens and lichenicolous fungi recorded on Quercus rubra in Poland

\begin{tabular}{|c|c|c|c|}
\hline \multirow[t]{2}{*}{ Species } & \multirow[t]{2}{*}{ Literature data } & \multicolumn{2}{|c|}{ Olsztyn Lake District } \\
\hline & & $\begin{array}{l}\text { Number } \\
\text { of sites }\end{array}$ & Site location \\
\hline \multicolumn{4}{|c|}{ Lichenized fungi (lichens) } \\
\hline Amandinea punctata (Hoffm.) & & 1 & NR \\
\hline $\begin{array}{l}\text { Coppins et Scheid. } \\
\text { Anisomerydium polypori (M.B. }\end{array}$ & & 1 & OL \\
\hline Ellis et Everh.) M.E. Barr & & & \\
\hline Arthonia radiata (Pers.) Ach. & $\begin{array}{l}\text { Ty s zk k i w w icz (1935), as } \\
\text { A. vulgaris Schaer f. astroidea Ach. }\end{array}$ & & \\
\hline Arthonia spadicea Leight. & & 1 & OL \\
\hline $\begin{array}{l}\text { Bacidina arnoldiana (Körb.) V. } \\
\text { Wirth et Vězda }\end{array}$ & & 1 & OL \\
\hline $\begin{array}{l}\text { Bacidina phacodes (Körb.) Vězda } \\
\text { Biatora efflorescens (Hedl.) }\end{array}$ & Kubiak (2005) & 4 & $\mathrm{NR}, \mathrm{OL}$ \\
\hline Erichsen & & & \\
\hline $\begin{array}{l}\text { Buellia griseovirens (Turner et } \\
\text { Borrer ex Sm.) Almb. }\end{array}$ & & 11 & LW, NR, OL \\
\hline $\begin{array}{l}\text { Chaenotheca chrysocephala } \\
\text { (Ach.) Th. Fr. }\end{array}$ & & 4 & $\mathrm{OL}$ \\
\hline $\begin{array}{l}\text { Chaenotheca ferruginea (Turner } \\
\text { ex Sm.) Mig. }\end{array}$ & & 1 & $\mathrm{OL}$ \\
\hline Cladonia coniocraea auct. & & 16 & $\begin{array}{l}\text { KG, LW, NR, } \\
\text { OL }\end{array}$ \\
\hline Cladonia digitata (L.) Hoffm. & & 1 & \\
\hline Cladonia fimbriata (L.) Fr. & & 6 & KG, LW, OL \\
\hline Dimerella pineti (Ach.) Vězda & & 9 & LW, OL \\
\hline Evernia prunastri (L.) Ach. & $\begin{array}{l}\text { Tyszkiewicz (1935), Glanc } \\
\text { (1969) }\end{array}$ & 9 & LW, NR, OL \\
\hline $\begin{array}{l}\text { Fuscidea arboricola Coppins et } \\
\text { Tønsberg }\end{array}$ & & 8 & $\begin{array}{l}\text { NR c.ap., } \\
\text { OL }\end{array}$ \\
\hline Fuscidea pusilla Tønsberg & & 2 & \\
\hline Graphis scripta (L.) Ach. & Tyszkiewicz (1935) & 4 & LW, OL \\
\hline $\begin{array}{l}\text { Hypocenomyce scalaris (Ach.) } \\
\text { Choisy }\end{array}$ & & 9 & $\begin{array}{l}\text { KG, LW, NR, } \\
\text { OL }\end{array}$ \\
\hline Hypogymnia physodes (L.) Nyl. & $\begin{array}{l}\text { Tyszki iewicz (1935), as Parmelia } \\
\text { physodes f. labrosa (L.) Ach.; Kukwa } \\
(2003)\end{array}$ & 16 & $\begin{array}{l}\text { KG, LW, NR, } \\
\text { OL }\end{array}$ \\
\hline Lecanora albella (Pers.) Ach. & $\begin{array}{l}\text { Ty s zkiewicz (1935), as } \\
\text { L. albella (Pers.) Ach. var. subalbella } \\
\text { Nyl., Ku biak (2005) }\end{array}$ & 1 & OL \\
\hline Lecanora argentata (Ach.) Malme & & 1 & LW \\
\hline Lecanora carpinea (L.) Vain. & & 1 & \\
\hline $\begin{array}{l}\text { Lecanora conizaeoides Nyl. ex } \\
\text { Crombie }\end{array}$ & $\begin{array}{l}\text { Gla n c et al. (1971), as } \\
\text { L. conizea (Ach.) Nyl. }\end{array}$ & 3 & KG, OL \\
\hline Lecanora expallens Ach. & Ku kwa (2002) & 3 & $\mathrm{NR}, \mathrm{OL}$ \\
\hline Lecanora pulcaris (Pers.) Ach & $\begin{array}{l}\text { Glanc et al. (1971), as } \\
\text { L. chlarona }\end{array}$ & 10 & $\mathrm{KG}, \mathrm{LW}, \mathrm{OL}$ \\
\hline Lecidella subviridis Tønsberg & & 1 & OL \\
\hline $\begin{array}{l}\text { Lecidella eleaochroma (Ach.) } \\
\text { Choisy }\end{array}$ & $\begin{array}{l}\text { Tyszkiewicz (1935), as Lecidea } \\
\text { parasema Ach. }\end{array}$ & & \\
\hline Lepraria elobata Tønsberg & & 5 & LW, OL \\
\hline Lepraria incana (L.) Ach. & & 13 & LW, NR, OL \\
\hline Lepraria jackii Tønsberg & & 3 & $\mathrm{KG}, \mathrm{OL}$ \\
\hline Lepraria lobificans Nyl. & & 4 & \\
\hline Lepraria rigidula (B. de Lesd.) & & 4 & KG, LW, NR, \\
\hline Melanelia fuliginosa (Fr. ex Duby) & Tyszkiewicz (1935), as & 11 & LW, KG, OL \\
\hline Essl. & $\begin{array}{l}\text { Parmelia fuliginosa (E.Fr.) Nl.; } \\
\text { D zi i b b s z e w sk i (1962), as } \\
\text { Parmelia fuliginosa (Fr.) Nyl. }\end{array}$ & & \\
\hline
\end{tabular}




\begin{tabular}{|c|c|c|c|}
\hline Melanelia olivacea (L.) Essl. & $\begin{array}{l}\text { Tyszki e wicz (1935), as Parmelia } \\
\text { olivacea (L.) Nyl. }\end{array}$ & \multirow[b]{3}{*}{9} & \multirow[b]{3}{*}{ LW, NR, OL } \\
\hline Melanelia subarifera (Nyl.) Essl. & $\begin{array}{l}\text { Gla n c (1969), as Parmelia subarifera } \\
\text { Nyl. }\end{array}$ & & \\
\hline Micarea prasina Fr. & $\begin{array}{l}\text { Gla n c (1969), as Catillaria prasina } \\
\text { (Fr.) Th.Fr.; Ku kwa (2002) }\end{array}$ & & \\
\hline $\begin{array}{l}\text { Mycoblastus fucatus (Stirt.) } \\
\text { Zahlbr. }\end{array}$ & & 14 & $\begin{array}{l}\text { KG, LW, NR, } \\
\text { OL }\end{array}$ \\
\hline $\begin{array}{l}\text { Ochrolechia androgyna (Hoffm.) } \\
\text { Arnold }\end{array}$ & & 10 & NR, LW, OL \\
\hline Ochrolechia microstictoides Räs. & & 3 & NR, OL \\
\hline $\begin{array}{l}\text { Ochrolechia turneri (Sm.) } \\
\text { Hasselrot }\end{array}$ & & 1 & LW \\
\hline Parmelia saxatilis (L.) Ach. & & 3 & $\mathrm{LW}, \mathrm{OL}$ \\
\hline Parmelia sulcata Taylor & $\begin{array}{l}\text { Tyszkiewicz (1935), Kukwa } \\
(2002)\end{array}$ & 12 & $\begin{array}{l}\text { LW c.ap., } \\
\text { OL }\end{array}$ \\
\hline $\begin{array}{l}\text { Parmeliopsis ambigua (Wulfen ex } \\
\text { Jacq.) Nyl. }\end{array}$ & $\begin{array}{l}\text { Dziabaszewski (1962), Kukwa } \\
(2002)\end{array}$ & 1 & $\mathrm{OL}$ \\
\hline Pertusaria amara (Ach.) Nyl. & $\begin{array}{l}\text { Dziabaszewski (1962), Kukwa } \\
\text { (2002) }\end{array}$ & 14 & LW, NR, OL \\
\hline Pertusaria coccodes (Ach.) Nyl. & & 7 & $\begin{array}{l}\text { KG, LW, NR, } \\
\text { OL }\end{array}$ \\
\hline $\begin{array}{l}\text { Pertusaria pertusa (Weigel.) Tuck. } \\
\text { var. pertusa }\end{array}$ & $\begin{array}{l}\text { Tyszkiewicz (1935), as } \\
\text { P. communis D.C. }\end{array}$ & & \\
\hline $\begin{array}{l}\text { Phlyctis argena (Ach.) Flot. } \\
\text { Physcia adscendens (Fr.) H. }\end{array}$ & $\begin{array}{l}\text { Kukwa (2002) } \\
\text { Tyszkiewicz (1935) }\end{array}$ & 12 & LW, NR, OL \\
\hline $\begin{array}{l}\text { Physconia distorta (With.) J.R. } \\
\text { Laundon }\end{array}$ & $\begin{array}{l}\text { Tys zkiewicz (1935), as Physcia } \\
\text { pulverulenta (Hoffm.) Nyl. }\end{array}$ & & \\
\hline $\begin{array}{l}\text { Placynthiella icmalea (Ach.) } \\
\text { Coppins et P. James }\end{array}$ & & 1 & KG \\
\hline $\begin{array}{l}\text { Platismatia glauca (L.) W.L. Culb. } \\
\text { et C.F. Culb. }\end{array}$ & Kukwa (2002) & 15 & LW, NR, OL \\
\hline $\begin{array}{l}\text { Pseudevernia furfuracea (L.) } \\
\text { Zopf. }\end{array}$ & & 3 & KG, LW, NR \\
\hline $\begin{array}{l}\text { Pseudosageda aenea (Wallr.) } \\
\text { Hafellner et Kalb }\end{array}$ & & 2 & OL \\
\hline Ramalina farinacea $(\mathrm{L}$.$) Ach.$ & $\begin{array}{l}\text { Tyszkiewicz (1935) } \\
\text { Tyszkiewicz (1935) }\end{array}$ & 2 & $\mathrm{OL}$ \\
\hline Ramalina pollinaria (Westr.) Ach. & $\begin{array}{l}\text { Tyszkiewicz } \\
\text { Glanc (1969) }\end{array}$ & & \\
\hline $\begin{array}{l}\text { Ropalospora viridis (Tønsberg) } \\
\text { Tønsberg }\end{array}$ & & 7 & LW, OL \\
\hline $\begin{array}{l}\text { Scoliciosporum chlorococcum } \\
\text { (Graeve ex Stenh.) Vězda }\end{array}$ & $\begin{array}{l}\text { Glan c (1969), as Bacidia } \\
\text { chlorococca (Graeve) Lett. }\end{array}$ & 1 & KG \\
\hline Usnea filipendula Stirt. & & 2 & LW, OL \\
\hline $\begin{array}{l}\text { Usnea subfloridana Stirt. } \\
\text { Vulpicidia pinastri (Scop.) J. E. }\end{array}$ & & 2 & $\begin{array}{l}\text { LW, OL } \\
\text { LW, OL }\end{array}$ \\
\hline $\begin{array}{l}\text { Xanthoria polycarpa (Hoffm.) } \\
\text { Rieber }\end{array}$ & & 1 & KG \\
\hline & Lichenicolous fungi & & \\
\hline $\begin{array}{l}\text { Chaenothecopsis pusilla (Ach.) A. } \\
\text { F.W. Schmidt (on wood) }\end{array}$ & & 1 & OL \\
\hline $\begin{array}{l}\text { Clypeococcum hypocenomycis } \\
\text { D. Hawksw. (on Hypocenomyce } \\
\text { scalaris) }\end{array}$ & & 1 & KG \\
\hline $\begin{array}{l}\text { Lichenoconium erodens M.S. } \\
\text { Christ. et D. Hawksw. (on } \\
\text { Lecanora conizaeoides and } \\
\text { Hypogymnia physodes) }\end{array}$ & & 1 & KG \\
\hline $\begin{array}{l}\text { Monodictys epilepraria Kukwa et } \\
\text { Diederich (on Lepraria sp.) }\end{array}$ & Kukwa (2004) & 1 & OL \\
\hline
\end{tabular}

Abbreviations: KG Kamienna Góra reserve; LW Las Warmiński reserve; OL Olsztyn city forests; NR Nowe Ramuki Forest District; c. ap. cum apotheciae 
whose ecological preferences are poorly known belong to this group. One of the first records of Lecidella subviridis in Lowland Poland was also identified (cf. Cza r n ot a, Kukwa 2003; Kukwa 2006).

Lichens were observed not only on the bark of tree trunks but also on exposed dead trunk wood and branches fallen on the ground. The following taxa were recorded on dead wood: Anisomerydium polyporii, Chaenotheca chrysocephala, Chaenothecopsis pusilla, Hypocenomyce scalaris, Lepraria incana and Cladonia sp. It was the only occurrence substrate of two species: Anisomerydium polyporii and Chaenothecopsis pusilla. The following species occurred on fallen branches: Hypogymnia physodes, Lecanora conizaeoides, L. pulicaris, Lichenoconium erodens (on a thallus of Lecanora conizaeoides), Pseudevernia furfuracea, Scoliciosporum chlorococcum and Xanthoria polycarpa. Two of them, Lichenoconium erodens and Xanthoria polycarpa, were recorded exclusively on this substrate.

The recorded biota includes 11 species threatened with extinction in Poland (19.6\%), including two endangered species (EN): Lecanora albella and Usnea subfloridana, four vulnerable species (VU): Biatora efflorescens, Ochrolechia androgyna, Ramalina farinacea and Usnea filipendula, and five near threatened species (NT): Bacidina arnoldiana, Evernia prunatri, Graphis scripta, Pertusaria coccodes and Vulpicidia pinastri. Four of them are threatened in North-Eastern Poland, including one endangered species: Lecanora albella, two vulnerable species: Bacidina arnoldiana and Biatora efflorescens, and one data deficient lichen (DD): Fuscidea arboricola (Fig. 4). Ten (17.9\%) of the species given are protected in Poland, including one partially protected (Evernia prunastri) and 9 fully protected (Melanelia fuliginosa, Parmelia saxatilis, Parmeliopsis ambiqua, Platismatia glauca, Pseudevernia furfuracea, Ramalina farinacea, Usnea filipendula, Usnea subfloridana, Vulpicidia pinastri).

\section{DISCUSSION}

Quercus rubra is mostly a large tree with a thick, straight, regular trunk and a wide, spreading crown. Outer bark in young red oaks, up to 40 years old, is smooth, steel-grey or dark grey, and furrowed or with flat-topped ridges in old trees. Quercus rubra differs from native oaks $(Q$. robur, $Q$. petraea) both by the habit as well as the structure and thickness of outer bark. The trunk of Quercus robur, which tends to branch out low above the ground (massive lateral boughs), is covered with thick, deeply furrowed, dark brown outer bark. Both these features as well as other factors influence species composition of lichens associated with this phorophyte. These differences are emphasised by Barkman (1969), who classifies Quercus rubra along such porophytes as Fagus sylvatica and young specimens of Quercus robur and $Q$. petraea. Chemical properties of Fagus sylvatica periderm (low $\mathrm{pH}$ ) are similar to those of Quercus robur and Q. petraea; it differs from them, however, by the bark relief and the crown shape. These differences are not as pronounced in the case of red oak and beech.

The lichen biota of both oak and beech has not been studied extensively in Poland. Rutkowski and Kukwa (2000) list 88 taxa, including 51 beech epiphytes and 77 oak epiphytes, in their analysis of the lichen biota of beech trees (Fagus sylvatica) and native oaks (Quercus robus and Q. petraea) in 24 sites in Northern Poland. The list comprises 40 taxa common for both trees $(45.4 \%)$. 
As these findings show, the lichen biota of red oak seems to be quite diversified and is comparable with native oaks, and especially beech. It should be stressed, however, that the study by Rut kows ki and Ku kw a (2000) does not fully reflect species differentiation of its epiphytes in Northern Poland, particularly oak. It only includes a small number of sites in North-Eastern Poland, where, according to Cieśliński (2003a), 234 lichens of this phorophyte were recorded. Cieśliński (2003a), however, does not differentiate oak species, and the findings may concern various taxa. Therefore, the information provided by Rutkowski \& Kukwa (2000) is of greater value in the assessment of lichen biotas of native oak species and beech and red oak. The similarity of lichen biotas (Jaccard's coefficient) of native oaks and beech, given in the study by Rutkowski and Kukwa (2000), and the lichen biota of red oak is $32 \%$ for red oak and native oaks, and is slightly higher and equals $34 \%$ for red oak and beech. The total, aggregated number of epiphytes of oak and beech equals 109, including 22 taxa recorded exclusively on the bark of Quercus rubra.

The provided data show that the phorophytic profile of Quercus rubra significantly differs from that of other, native oak species. The species has its own specific lichen biota which consists of many interesting taxa. As a result of the review of the Polish lichenological literature, additional 19 lichen species reported from the bark of red oak were recorded. Of those, 11 taxa were not observed in the Olsztyn Lake District. The list of lichens of red oak in Poland comprises in total 63 lichen species and 4 species of lichenicolous fungi. This biota should be considered to be rich, especially as its differentiation appears to be similar to that recorded in the areas of the native range of this phorophyte. The number of taxa colonising the bark of Quercus rubra in its native occurrence range is small although the fact that its trunks are often abundantly covered by lichens is stressed (cf. Stubbs 1989; May 2001). Hale (1955) reports 45 lichen species from the southern part of Wisconsin, and Culberson (1955) reports 41 species from the northern part of the state. Stubbs (1989) presents 32 taxa (15 fruticose and foliose and 17 crustose) from the sites in Main. The number of lichens of this important phorophyte in this region usually does not exceed 10 in numerous local studies on the north-western part of North America (Hyerczyk 1996, 1998; May 2001).

As the surface area covered by deciduous forests of the class Querco-Fagetea, associated with the richest lichen biotas in lowland regions, has been declining (Czyżews ka 2003), Quercus rubra, a phorophyte characterised by a broad ecological scale and potentially rich lichen biota, may play an important role in the preservation of lichen species diversity in forest phytocoenoses. The biocoenotic function of red oak, underestimated so far, may be of certain use in cultivated forests located outside or on the limit of the native occurrence of beech. Special attention should be paid to the occurrence of Lecanora albella, a species belonging to a group of lowland old-growth forest indicators, on the bark of red oak (cf. Cieśliński, Czyżewska, Fabiszewski 2003). The phorophyte has been reported on the bark of red oak both in the Olsztyn Lake District and Gdańsk Pomerania (Tyszkiewicz 1935). According to Fałtynowicz (1991), Lecanora albella is in particular associated with beech bark in Western Pomerania. It occurs on a variety of deciduous species in North-Eastern Poland (Cieśliński 2003a) and exemplifies ecological vicarism (cf. Barkman 1969; Fałtynowicz 1991; Zalewska 2000). In the Olsztyn Lake 
District, the species was recorded in the city forest in Olsztyn where many other lichen lowland old-growth forest indicators also occur (Kubiak 2005).

\section{CONCLUSIONS}

1. The epiphytic biota of Quercus rubra as a phorophyte is characteristic, diversified and rich, and it comprises 63 lichen species and 4 species of lichenicolous fungi.

2. Species of rare lichens, both threatened with extinction (Lecanora albella, Melanelia olivacea, Ochrolechia androgyna, Usnea subfloridana) and differentiated very rarely (Fuscidea arboricola, F. pusilla, Lecidella subviridis, Ropalospora viridis), were recorded on the bark of red oak in Poland.

3. As well as having many biocoenotic functions, red oak may play an important role in preserving lichen biodiversity in the forest environment in Poland.

Acknowledgements: The author would like to thank Dr. Martin Kukwa, Department of Plant Taxonomy and Nature Protection, University of Gdańsk, for his kind help in determining selected lichen specimens. He would also like to thank the anonymous Reviewer for valuable comments and remarks.

\section{REFERENCES}

Alvarez J., Carballal R. 2000. Flora liquenica sobre Quercus robur L. en Galicia (N W Espana). Cryptogamie, Mycol. 21 (2): 103117.

B a rkm an J. 1969. Phytosociology and ecology of cryptogamic epiphytes. Van Gorcum, Assen.

Boratyńska K. 1979. Dąb bezszypułkowy (Quercus petraea (Mat.) Liebl.) w północno wschodniej Polsce. Arboretum Kórnickie 24: 6985.

Boratyński A. 1979. Występowanie jaworu (Acer pseudoplatanus L.) w Polsce. Arboretum Kórnickie 24:19 67.

Browicz K. 1953. Dęby uprawiane w Polsce. Rocznik Sek. Dendrol. 9: 8688.

Bug ała W. 1991. Drzewa i krzewy dla terenów zieleni. PWRiL, Warszawa.

Cieślińs ki S. 2003 a. Atlas rozmieszczenia porostów (Lichenes) w Polsce Północno Wschodniej. Phy tocoenosis 15 (N.S.). Suppl. Cartogr. Geobot. 15.

Cieślińs ki S. 2003 b. Czerwona lista porostów zagrożonych w Polsce Północno Wschodniej. Monogr. Bot. 91: 91106.

Cieśliński S., Czyżewska K., Fabiszewski J. 2003. Czerwona Lista porostów wymarłych i za grożonych w Polsce. Monogr. Bot. 91: 1349.

Cieśliński S., Tobolewski Z. 1988. Porosty (Lichenes) Puszczy Białowieskiej i jej zachodniego przedpola. Phytocoenosis 1 (N. S.), Suppl. Cartogr. Geobot. 1: 1216.

Coulbers on W. L. 1955. The corticolous communities of lichens and bryophytes in the Upland forest of Northern Wisconsin. Ecoll. Monogr. 25 (1): 215231.

Czarnota P., Kukwa M. 2003. Some sorediate lichens and lichenicolous fungi new to Poland. Gra phis Scripta 15: 2432.

Czyżews k a K. 2003. Ocena zagrożenia bioty porostów Polski. Monogr. Bot. 91: 241249.

Danielewicz W., Pawlaczyk P. 2006. Rola dębów w strukturze i funkcjonowaniu fitocenoz. (In:) W. B u g a ł a (ed.). Dęby. Nasze drzewa leśne 11: 475 590. Instytut Dendrologii PAN, Poznań Kórnik.

Dzia b a szews ki B. 1962. Porosty okolic Poznania na tle porostów Wielkopolski. PTPN Prace Komisji Biol. 22 (4): 1159.

Engel K., Detsch R., Ammer U., Hertel H. 2003. Importance of different tree species for epi phytic lichen Surveys in three flood plain forests of the River Danube in Bavaria. Naturschutz und Landschaftsplanung 35 (10): 311316.

Fałtynowicz W. 1991. Porosty Pomorza Zachodniego. Studium ekologiczno geograficzne. Uniwersy tet Gdański, Gdańsk. 
Fałtynowicz W. 2003. The lichens, lichenicolous and allied fungi of Poland. An annotated checklist. W. Szafer Institute of Botany Polish Academy of Sciences, Kraków, 435 pp.

Gla n c K. 1969. Flora porostów Arboretum w Gołuchowie. PTPN Prace Komisji Nauk Roln. i Komisji Nauk Leśn. 28: 127141.

Glanc K., Kapuściński R., Król I. 1971. Flora porostów Okręgu Baryckiego w Krainie Wielkopol sko Kujawskiej. Prace Komisji Nauk Roln. i Komisji Nauk Leśn. PTPN 32: 2337.

Hale M. E. 1955. Phytosociology of corticolous cryptogams in the upland forests of Southern Wisconsin. Ecol. 36 (1): 4563.

Heré́niak J. 1992. Amerykańskie drzewa i krzewy na ziemiach polskich. (In:) M. Ławrynowicz, U. Wa r cholińska (eds). Rośliny pochodzenia amerykańskiego zadomowione w Polsce. Łódzkie Tow. Nauk., Łódź: 97150.

Hye rczyk R. D. 1996. The Lichen Flora of Putnam County, Illinois. Transactions of the Illinois State Academy of Science 89 (3): 143156.

Hyerczyk R. D. 1998. The Lichen Flora of the St. Charles Park District Natural Areas. Transactions of the Illinois State Academy of Science 91 (4): 123133.

Jutrzenka Trzebiatowski A., Fenyk M. A. 2001. Wpływ klimatycznych czynników borealnych na kształtowanie się zbiorowisk leśnych Polski północno wschodniej. Acta Bot. Warmiae et Masuriae 1: 2549.

Kondracki J. 1998. Geografia regionalna Polski. PWN, Warszawa.

Król S. 1967. Dąb czerwony Quercus rubra L. w warunkach środowiska leśnego zachodniej Polski. PTPN, Prace Kom. Nauk Roln. i Kom. Nauk Leśn. 21: 419482.

Kubiak D. 2005. Lichens and lichenicolous fungi of Olsztyn town (NE Poland). Acta Mycol. 40 (2): 293332.

Ku kwa M. 2006. Nowe stanowiska rzadkich i interesujących porostów na Pomorzu Gdańskim. III. Acta Bot. Cassub. 6 (in press).

Kukwa M., Diederich P. 2005. Monodictys epilepraria, a new species of lichenicolous hyphomycetes on Lepraria. Lichenologist 37: 217220.

Matuszkiewicz J. M. 2001. Zespoły leśne Polski. PWN, Warszawa.

May P. F. 2001. Lichen survey of Mount Everett Summit, Southwest Berkshire County, Massachusetts. htttp://www.mounteverett.org/Studies/Lichen.pdf

Modrzyński J., Robakowski P., Zientarski J. 2006. Zarys ekologii. (In:) W. Bugała (ed.). Dęby. Nasze drzewa leśne 11. Instytut Dendrologii PAN, Poznań Kórnik: 411474.

Orange A., James P. W., White F. J. 2001. Microchemical methods for the identification of lichens. British Lichen Society, London.

Podbielkowski Z. 1995. Fitogeografia części Świata. Ameryka, Australia, Oceania, Antarktyda. PWN, Warszawa

Rut kowski P. 1995. Flora porostów na dębach w Polsce w świetle dotychczasowych doniesień literatu rowych. Materiały konferencji i sympozjów 50 Zjazdu PTB, Kraków: 336.

Rutkowski P., Kukwa M. 2000. Materiały do znajomości flory epifitycznych porostów dębów i bu ków w północnej Polsce. Bad. Fizjogr. Pol. Zach. 49: 207215.

St ubbs C. S. 1989. Patterns of distribution and abundance of corticolous lichens and their invertebrates associates in Quercus rubra in Main. Bryologist 92: 453460.

Szy ma now ski T. 1959. Zagadnienia aklimatyzacji obcych drzew w Polsce. Ochr. Przyr. 26: 261319.

To kar z H. 1971. Zbiorowiska leśne z udziałem buka (Fagus sylvatica) w obszarze północno wschodniej granicy jego zasięgu. 1. Acta Biol. Med. Soc. Sc. Gedan. 15 (3): 227274.

Tu miłow icz J. 1965. Abies balsamea Mill. i Abies concolor Lindl. et Gord. w lasach Pomorza Wschod niego. Rocz. Sek. Dendr. PTB 19: 151159.

Tumiłowicz J. 1967. Ocena warunków wprowadzenia niektórych obcych gatunków drzew w lasach Krainy Mazursko Podlaskiej. 1. Rocz. Sek. Dendr. PTB 21: 135169.

Tyszki ew ic z J. 1935. Badania nad występowaniem porostów nadrzewnych w lasach północno wschod niej części wyżyny Kielecko Sandomierskiej. Planta Polonica III: 1119.

Zalewska A. 2000. Ekologia porostów Puszczy Boreckiej i jej obrzeży. Studium bioróżnorodności. Praca doktorska (msc.). Uniwersytet Warmińsko Mazurski w Olsztynie, Olsztyn.

Zalewska A., Fałtynowicz W., Krzysztofiak A., Krzysztofiak L., Picińska Fałtynowicz J. 2004. Porosty Puszczy Rominckiej. Stowarzyszenie „Człowiek i Przyroda”, Suwałki.

Za ręb a R. 1978. Puszcze, lasy i bory Polski. PWRiL, Warszawa. 
Zed d a L. 2002. The epiphytic lichens on Quercus in Sardinia (Italy) and their value as ecological indica tors. Englera 24: 1468.

\section{Porosty dębu czerwonego Quercus rubra w środowisku leśnym Pojezierza Olsztyńskiego}

\section{Streszczenie}

W wyniku przeprowadzonych badań własnych oraz przeglądu krajowej literatury licheno logicznej odnotowano 63 gatunki porostów oraz 4 gatunki grzybów naporostowych występują cych na korze Quercus rubra. Podczas szczegółowych badań nad porostami epifitycznymi tego forofitu, przeprowadzonych na 16 stanowiskach w lasach Pojezierza Olsztyńskiego, stwierdzo no 56 taksonów, w tym szereg gatunków rzadkich. Wyróżniona na obszarze Pojezierza biota liczy 11 gatunków umieszczonych na krajowej „Czerwonej Liście” oraz 14 porostów objętych ochroną gatunkową. Do szczególnie interesujących taksonów zaliczyć należy: Fuscidea arbori cola, Lecanora albella, Lecidella subviridis, Ochrolechia androgyna i O. turneri. 